\title{
ЗАГАЛЬНА ХАРАКТЕРИСТИКА ОРГАНІЗАЦІЇ ОПЕРАТИВНО-РОЗШУКОВОЇ ДІЯЛЬНОСТІ ТА НЕГЛАСНОЇ РОБОТИ НАЦІОНАЛЬНОЇ ПОЛІЦІЇ УКРАЇНИ
}

Князєв С. М.

\begin{abstract}
у статmі досліджено поняття організації оперативно-розшукової діяльності та негласної роботи Національної поліції України. Виокремлено рівні та напрями організації діяльності оперативних підрозділів. Зосереджено увагу на основних елементах такої організації діяльності, а саме: вивчення, аналіз та оцінка оперативної обстановки на об'єкті обслуговування; розстановка сил, засобів опе ративними підрозділами; планування оперативно-розшукової діяльності; взаємодія оперативних підрозділів між собою та з іншими підрозділами правоохоронного органу, центральними органами виконавчої влади; контроль виконання запланованих заходів. Зроблено висновок, що організацію оперативно-розшукової діяльності та негласноі роботи оперативних підрозділів Національної поліції України необхідно розглядати у двох аспектах - статичному i динамічному, тобто як стан керованої сочіальної системи та як дії посадових осіб, що відповідають значенню дієслова «організовувати». Організація оперативно-розшукової діяльності та негласної роботи знаходить своє формальне вираження в положеннях нормативно-правових актів, що регулюють суспільні відносини у сфері оперативно-розшукової діяльності. Змістом організації оперативно-розшукової діяльності та негласної роботи є дії відповідних посадових осіб: 1) зі створення керованих систем (організаційних структур) у сфері оперативно-розшукової діяльності та негласної роботи, упорядкування (розвиток) цих систем до рівня, що забезпечує найбільшу ефективність вирішення завдань оперативно-розшукової діяльності та негласної роботи в певній оперативній обстановці; 2) упорядкування (налагодження) процесу управління (його окремих стадій) у сфері оперативно-розшукової діяльності та негласної роботи й забезпечення оптимальних умов для прийняття і реалізації відповідних управлінських рішень; 3) що є Складовими управлінського циклу, тобто сам процес управління оперативно-розшукової діяльності; 4) зі створення умов, необхідних для конкретних оперативно-розшукових заходів.
\end{abstract}

Ключові слова: організація, оперативно-розшукова діяльність, негласна робота, слідчі (розшукові) діi, негласні слідчі (розшукові) діi, оперативно-розшукові заходи, Національна поліція України.

В статье исследовано понятие организации оперативно-розыскной деятельности и негласной работы Национальной полиции Украины. Выделены уровни и направления организации деятельности оперативных подразделений. Исследование сосредоточено на основных элементах такой организации деятельности, а именно: изучение, анализ и оценка оперативной обстановки на объекте обслуживания; расстановка сил, средств оперативными подразделениями; планирование оперативно-розыскной деятельности; взаимодействие оперативных подразделений между собой и с другими подразделениями правоохранительных органов, центральными органами исполнительной власти;

Князєв С. М., 2019 контроль выполнения запланированных мероприятий. Сделан вывод, что организация оперативно-розыскной деятельности и негласного работы оперативных подразделений Национальной полиции Украины необходимо рассматривать в двух аспектах - статическом и динамическом, то есть как состояние управляемой социальной системы и как действия должностных лиц, отвечающих значению глагола «организовывать». Организация оперативно-розыскной деятельности и негласного работы как состояние системы находит свое формальное выражение в положениях нормативно-правовых актов, регулирующих общественные отношения в сфере оперативно-розыскной деятельности. Как деятельность соответствующих должностных лиц содержанием организации оперативно-розыскной деятельности и негласной работы являются следующие действия: 1) по созданию управляемых систем (организационных структур) в сфере оперативно-розыскной деятельности и негласной работы, благоустройство (развитие) этих систем до уровня, обеспечивающего наибольшую эффективность решения задач оперативно-розыскной деятельности и негласного работы в определенной оперативной обстановке; 2) составления (настройка) процесса управления (его отдельных стадий) в сфере оnеративно-розыскной деятельности и негласного работы и обеспечение оптимальных условий для принятия и реализации соответствующих управленческих решений; 3) что является составляющими управленческого цикла, то есть сам процесс управления оперативно-розыскной деятельности; 4) по созданию условий, необходимых для конкретных оперативно-розыскных мероприятий.

Ключевые слова: организация, оперативно-розыскная деятельность, негласная работа, следователи (розыскные) действия, негласные следственные (розыскные) действия, оперативно-розыскные мероприятия, Национальная полиция Украины.

The article explores the notion of organizing operational and search activities and silent work of National Police of Ukraine. The levels and directions of organization of activity of operational units are distinguished. The focus is on the main elements of such an organization of activity, namely: the study, analysis and evaluation of the operational situation at the facility; deployment of forces, means by operational units; planning of operational and search activities; interaction of operational units with each other and with other units of law enforcement, central executive authorities; control over the implementation of planned activities. It is concluded that organization of operational-search activities and silent work of the operational units of National Police of Ukraine should be considered in two aspects - static and dynamic, is as the state of a managed social system and as the actions of officials corresponding to the meaning of the verb "to organize". Organization of operative-search activity and silent work as a state of the system finds its formal expression in the provisions of normative-legal acts that regulate public relations in the field of operational-search activity. As the activities of the respective officials, the content of orga- 
nization of operational and search activities and silent work are actions: 1) to create managed systems (organizational structures) in the field of operational and search activities and silent work, ordering (development) of these systems to the level that provides the highest efficiency solving tasks of operational search activity and silent work in a certain operational environment; 2) streamlining (adjusting) the process of management (its individual stages) in the field of operational and search activities and imprudent work and ensuring optimal conditions for making and implementing appropriate management decisions; 3) what are the components of the management cycle, that is, the very process of managing the operational and search activities; 4) to create the conditions necessary for specific operational-search measures.

Key words: organization, operative-search activity, unspoken work, investigative (search) actions, unspoken investigative (search) actions, operational-search activities, National Police of Ukraine.

Постановка проблеми та їі актуальність. Здійснюючи правоохоронну діяльність, працівники Національної поліції реалізують основне своє завдання - забезпечують захист життя, здоров'я, прав і свобод громадян, безпосереднім чином взаємодіючи 3 населенням. Одним із способів вираження цієї взаємодії $\epsilon$ право, в нормах якого знаходить свій прояв політика протидії злочинності, кримінальна політика як іiї складова, визначення особливостей правоохоронної i судової практики, компетенції і сфери діяльності правоохоронних органів, напрацювання інструментарію боротьби зі злочинністю, шляхів її превенції. Правоохоронна діяльність, як втілення правової реальності, насичена соціально-психологічними явищами. Це й правова психологія спільнот і груп, і психологія особистості, яка живе та діє в даній групі, і система її взаємовідносин із правом. Тому переважна частина проблем правоохоронної діяльності може бути вирішена лише в сукупності правового й соціальних контекстів.

Аналіз останніх досліджень і публікацій, в яких започатковано розв'язання даної проблеми. Вирішення проблеми його розуміння започатковано у працях Д.В. Гребельського, А.Г. Лєкаря, М.П. Лашина, В.А. Лукашова та інші. В Україні окреслені питання розглядали О.М. Бандурка, В.О. Глушков, М.Л. Грібов, О.М. Джужа, О.Ф. Долженков, Е.О. Дідоренко, І.П. Козаченко, О.І. Козаченко, Д.Й. Никифорчук, С.В. Обшалов, К.М. Ольшевський, Ю.Ю. Орлов, М.А. Погорецький, В.Л. Регульський, І.І. Приполов, І.В. Сервецький, В.Д. Сущенко, В.О. Черков, В.П. Шеломенцев та інші.

Досліджуючи означені питання, вчені здебільшого ґрунтувалися на комплексному аналізі загальновживаного значення слова «організація», тлумаченні цього поняття у філософії, а також в теорії державного управління загалом та в теорії управління органами внутрішніх справ (ОВС) зокрема.

Метою статті $\epsilon$ : дати загальну характеристику організації оперативно-розшукової діяльності та негласної роботи національної поліції України.

Виклад основного матеріалу. Питання, пов'язані з організацією діяльності підприємства, досліджувало багато зарубіжних та вітчизняних авторів [1; 2; 3 та інші].

Комплексний аналіз поглядів представників різних наукових спеціальностей на сутність організації дає підстави для висновку, що це поняття необхідно розглядати у двох аспектах - статичному й динамічному, зокрема, як стан керованої соціальної системи та як дії посадових осіб, які відповідають значенню дієслова «організовувати». Це повним обсягом може бути застосовано в площині оперативно-розшукової діяльності (далі ОРД - С. К.) та негласної роботи.

ОРД та негласна робота як керована соціальна система передбачає:

- мету та завдання власного існування;

підрозділи, уповноважені на здійснення ОРД, та їх внутрішні структурні утворення;

функції, повноваження, сили та засоби діяльності оперативно-розшукових підрозділів та їх внутрішніх структурних утворень;

взаємозв'язки та взаємообумовленість будови зазначеної системи і функцій, покладених на оперативно-розшукові підрозділи, їх внутрішні структурні утворення, а також сили та засоби їх діяльності;

підстави, зміст та порядок взаємодії оперативних підрозділів та їх внутрішніх структурних утворень при здійсненні ОРД та негласних слідчих (розшукових) дій (далі НСРД - С. К.).

Зазначені елементи ОРД як соціальної керованої системи становлять їі зміст та $є$ основними ознаками iї стану. Організація ОРД як стан системи формально виражена в положеннях нормативно-правових актів, які регулюють суспільні відносини у сфері ОРД. Як діяльність відповідних посадових осіб змістом організації ОРД є дії щодо:

створення керованих систем (організаційних структур) у сфері ОРД, упорядкування (розвиток) цих систем до рівня, що забезпечує найбільшу ефективність вирішення завдань ОРД у певній оперативній обстановці;

упорядкування (налагодження) процесу управління (його окремих стадій) у сфері ОРД та забезпечення оптимальних умов для прийняття і реалізації відповідних управлінських рішень;

управлінського циклу, тобто сам процес управління ОРД;

створення умов, необхідних для конкретних оперативно-розшукових заходів (далі ОРЗ - С. К.).

Наука і практика управління, зокрема у правоохоронній сфері, виокремлюють організаціюяк засібдосягнення кінцевого результату діяльності. Оминаючи дискусії щодо дефініції «організації» як управлінської категорії, вважається прийнятним традиційне визначення елементів організації як процесу, зокрема: аналіз ситуації, планування, визначення та розстановка сил (підготовка i навчання виконавців), контроль і надання допомоги, забезпечення взаємодії суб'єктів виконання, матеріально-технічне і фінансове забезпечення, оцінка результатів роботи i, за необхідності, внесення корективів.

Зазначені підходи до розуміння змісту організації ОРД та негласної роботи, на жаль, не враховують те, що оперативні підрозділи не лише є суб'єктами ОРД, а й учасниками у кримінального процесі, адже відповідно до ст. 41 КПК України, набувають повноважень слідчого під час виконання його доручень на проведення слідчих (розшукових) дій (далі СРД - С. К.) та НСРД.

Унаслідок того, що значну частину діяльності оперативних підрозділів сьогодні становить їх робота в межах досудового розслідування, організацію контролю за цією діяльністю слід розглядати не лише в контексті теорії ОРД, а й із доктринальних позицій, усталених у кримінальній процесуальній науці [4; 5; 6]. 
На підставі результатів системного аналізу поглядів представників криміналістичної науки з цього питання, Д.Б. Сергєєва дійшла висновку, що переважна більшість науковців, не даючи визначення поняття організації, розкривають іï зміст через перерахування елементів. До того ж часто у визначення поняття організації включаються елементи, що стосуються як розслідування загалом, так і окремих засобів розслідування - слідчих дій [7, с. 239]. Д.Ю. В'юнник також зауважує, що суттєвим недоліком таких визначень $\epsilon$ те, що їх автори намагаються сформулювати поняття організації розслідування як універсальне щодо конкретного акту розслідування та всієї системи розслідування загалом [8, с. 5]. Для правильного визначення поняття організації розслідування, наголошував Р.С. Бєлкін, необхідно розрізняти рівні цієї діяльності, у зв'язку з чим він визначає останню як розумову діяльність слідчого, спрямовану на побудову уявної моделі всього акту розслідування, матеріальним вираженням якої і стає письмовий план у справі [9, с. 362]. Таку думку поділяють й інші науковці, які зазначають, що організація розслідування $\epsilon$ комплексом необхідних заходів на різних етапах розслідування, які забезпечують діяльність органів щодо розкриття, розслідування та попередження злочинів.

О.В. Олішевський, ґрунтуючись на комплексному аналізі наукових праць провідних російських учених-криміналістів, дійшов висновку, що рівень організації розслідування злочинів - це відносно відокремлена за своїм характером площина організації, яка обумовлена складністю структури та діяльності правоохоронних органів. На основі вищевикладеного вчений розмежовує рівні організації розслідування злочинів на управлінські та криміналістичні. Серед останніх він виокремлює такі:

1) організація слідчої чи іншої дії;

2) організація розслідування у кримінальній справі;

3) організація розслідування у кримінальних справах, що перебувають у провадженні одного слідчого.

Ці рівні $\epsilon$ частковим відображенням положень криміналістичних тактики та методики розслідування злочинів, а тому органічно вливаються в традиційну систему криміналістики. Науковець підкреслює, що вони є визначальними, оскільки все інше покликано так чи інакше обслуговувати діяльність, яка здійснюється в їх межах [10]. Аналогічні рівні можна виділити і в організації діяльності оперативних підрозділів.

Проте для того, щоб застосувати результати наукових розвідок О.В. Ольшевського щодо предмета нашого дослідження, при визначенні рівнів організації діяльності оперативних підрозділів не можна не враховувати обставини, які істотно відрізняють організацію ОРД та організацію досудового розслідування. По-перше, це наявність різних форм ОРД, які в теорії отримали назви «оперативна профілактика», «оперативний пошук», «оперативна розробка» (інколи виокремлюють таку форму як «оперативне супроводження кримінального судочинства»). У межах кожної з цих форм може проводитись комплекс заходів, що відображається у провадженні за справою окремої категорії та потребує відповідної організації. Водночас усі слідчі розшукові дії та НСРД здійснюють лише під час досудового розслідування та в межах кримінального провадження. По-друге, суб'єктами організації досудового розслідування $\epsilon$ лише слідчий та прокурор (як процесуальний керівник). Оперативні підрозділи, виконуючи їх доручення, можуть виступати лише як організатори конкретних слідчих розшукових дій та НСРД. По-третє, існують оперативні підрозділи, які діють винятково на засадах конспірації та спеціалізуються на проведені окремих ОРЗ та НСРД.

Зважаючи на вищезазначене, пропонуємо виокремлювати такі рівні організації діяльності оперативних підрозділів:

1) організація проведення конкретного ОРЗ або певної НСРД;

2) організація проведення комплексу OP3 у межах оперативної профілактики, оперативного пошуку, оперативної розробки, а також комплексу НСРД у межах кримінального провадження;

3) організація роботи спеціалізованого негласного підрозділу з одночасного виконання різних завдань і доручень на проведення ОРЗ та/або НСРД;

4) організація роботи конкретного оперативного підрозділу з проведення ОРД (зараховуючи організацію роботи з негласним апаратом, організацію оперативного обслуговування певних об'єктів і галузей, організацію аналітичної роботи) та виконання доручень слідчого, прокурора на проведення НСРД;

5) організація роботи системи оперативних підрозділів одного правоохоронного органу (зокрема, Національної поліції України);

6) організація роботи системи оперативних підрозділів усіх правоохоронних органів.

Аналіз означених рівнів організації діяльності оперативних підрозділів свідчить, що структура кожного з них відповідає класичним уявленням про зміст організації ОРД. Так, кожен із цих рівнів зараховує: вивчення, аналіз та оцінку оперативної обстановки (оперативно-тактичної або слідчої ситуації); планування діяльності (складання плану ОРЗ, НСРД, роботи оперативного підрозділу); розстановку сил і засобів оперативних підрозділів; організацію взаємодії; контроль.

Організація діяльності оперативних підрозділів на двох останніх, найвищих, рівнях (організація роботи системи оперативних підрозділів одного правоохоронного органу; організація роботи системи оперативних підрозділів усіх правоохоронних органів) не може бути ефективною без належного правового урегулювання статусу та повноважень оперативних підрозділів. Вади юридичного регулювання на цих рівнях спричиняють суттєві проблеми в організації роботи на інших.

Поряд з елементами змісту та рівнями організації ОРД варто виокремлювати іï напрями. Проведені дослідження засвідчили, що, відповідно до тлумачення поняття «напрям» як лінія руху, шляху розвитку можна виокремити два різновиди напрямів організації ОРД та негласної роботи.

Перший різновид - це організація ОРД та негласної роботи з конкретними видами боротьби зі злочинністю (відповідно до розділів та окремих статей Кримінального кодексу України, а також до окремих видів злочинів, що визначаються кримінологічною науковою). Зокрема, можна виокремлювати такі напрями, як організація ОРД та негласної роботи з протидії корисливо-насильницькій, організованій, корупційній та іншій злочинності, кримінальним правопорушенням у сфері громадського порядку та публічної безпеки, обігу наркотичних засобів, зброї та вибухівки, злочинів у сфері 
банківського кредитування, електроенергетики, транспорту тощо.

Другий різновид - це організація ОРД та негласної роботиза, відповідно до змісту, певнимивидамидіяльності оперативних підрозділів (негласне співробітництво; забезпечення конспірації; забезпечення безпеки осіб, які беруть участь у кримінальному судочинстві; інформаційно-аналітична робота; кримінальна розвідка).

Окреслені дії становлять практичну реалізацію положень нормативно-правових актів, що регулюють суспільні відносини у сфері ОРД [11, с. 66]. Отже, категорія «організація оперативно-розшукової діяльності та негласної роботи» тісно пов'язана з категорією правовідносин між об'єктами та суб'єктами управління у сфері діяльності оперативних підрозділів правоохоронних органів. Юридичний зміст цих правовідносин $€$ статичним та відповідає стану ОРД і негласної роботи як соціальної керованої системи. Фактичний відповідає реальним діям відповідних посадових осіб 3 реалізації положень відповідних нормативно-правових актів. Проте вся організація ОРД і негласної роботи (і як стан керованої системи і як діяльність) не охоплена правовим регулюванням. Тому організацію ОРД не можна ототожнювати зі змістом правовідносин між суб'єктами та об'єктами управління у сфері ОРД. Цей зміст доцільно розглядати лише як сукупність засад (основних, вихідних положень) організації ОРД, що слід означити як правові [11, с. 67].

Правові ж засади організації ОРД та негласної роботи являють собою сукупність урегульованих законодавством норм, якими встановлюється система суб'єктів та об'єктів управління в ОРД та негласній роботі, визначаються їх права й обов'язки. Засадами організації ОРД та негласної роботи варто вважати й науково обґрунтовані теоретичні положення щодо налагодження й упорядкування цієї діяльності, які не знайшли формального закріплення в нормативно-правових актах. Такі засади слід означити як наукові. Вони $\epsilon$ первинними щодо правових, оскільки наука завжди повинна передувати закону. На наукових засадах має ґрунтуватися не лише організаційна діяльність посадових осіб, що не охоплена правовим регулюванням, а й правові норми, які $\epsilon$ практичною основою організації ОРД та негласної роботи. Отже, наукові засади організації ОРД становлять систему науково обґрунтованих теоретичних положень, на яких має ґрунтуватися правове регулювання ОРД як керованої соціальної системи, та не охоплена правовим регулюванням діяльність об'єктів і суб'єктів управління в цій сфері.

Головною проблемою організації ОРД та негласної роботи Національної поліції України $є$ те, що її правові засади сформовані за відсутності наукового обґрунтування або ж ґрунтуються на положеннях, що пропонували ще радянські вчені. Це викликано тим, що наукові та практичні засади ОРД, сформовані в СРСР у другій половині минулого століття, багато в чому були успадковані теорією та практикою ОРД сучасної України. При цьому в роботах сучасних українських учених містяться посилання на праці ще 50-80-х років минулого століття.

Наукові постулати радянського часу щодо організації ОРД та негласної роботи часто використовуються без належного аналізу, а в окремих випадках подаються як аксіоми. Деякі з них, дійсно, можуть належати до категорії «засади організації ОРД та негласної роботи» та мають вагоме теоретичне i практичне значення. Вони здебільшого були модернізовані та пристосовані українськими вченими до сучасних умов. Проте значна частина положень та результатів досліджень радянських учених сьогодні застаріла, а окремі з них не були належним чином обґрунтовані.

До найбільш поширених аксіоматичних положень, успадкованих з радянських часів ученими багатьох країн пострадянського простору, $\epsilon$ те, що організація ОРД складається з таких елементів, як:

1) вивчення, аналіз та оцінка оперативної обстановки на об'єкті обслуговування;

2) розстановка сил, засобів оперативними підрозділами;

3) планування ОРД;

4) взаємодія оперативних підрозділів між собою та з іншими підрозділами правоохоронного органу, центральними органами виконавчої влади;

5) контроль виконання запланованих заходів $[12$, c. 285].

На думку багатьох дослідників, зазначені елементи $€$ основними, які обов'язково повинні входити в процес організації ОРД та негласної роботи.

Але навіть поверховий аналіз цього підходу дає підстави для висновків, що запропоновані елементи організації ОРД та негласної роботи накладаються один на одного та не можуть бути чітко розмежовані. Так, вивчення, аналіз й оцінка оперативної обстановки $є$ підготовчим етапом планування. Розстановка сил та засобів має бути невід'ємною частиною планування - обов'язковою складовою плану [13]. Шануючи наукові традиції теорії ОРД, проаналізуємо елементи змісту організації ОРД за традиційною схемою з метою визначення їх змісту та співвідношення (з відповідним критичним аналізом).

Вивчення, аналіз та оцінка оперативної обстановки на об'єкті обслуговування здійснюється на підставі отриманої оперативної інформації.

Оперативна обстановка (пізньолат. - той, що створює, формує, від лат. - діяти, працювати) - сукупність факторів (умов) внутрішнього і зовнішнього середовища, характер і зміст яких визначаються переліком оперативно-службових заходів впливу на конкретні напрями діяльності [14].

В основу аналізу та оцінки оперативної обстановки покладено:

1) середовище (територіально-географічні, соціально-економічні, демографічні, релігійні, етнічні та інші характеристики території, яка обслуговується підрозділами кримінальної поліції);

2) структура, динаміка, рівень кримінальних правопорушень та адміністративних правопорушень, дані про фігурантів протиправних діянь;

3) ефективність використання сил та засобів оперативного підрозділу, взаємодії з іншими державними органами, громадськими об'єднаннями та окремими особами у протидії кримінальним правопорушенням;

4) результати оперативно-службової діяльності із запобігання кримінальним правопорушенням, їх припинення, розкриття та розслідування.

Очевидно, що від повноти різнобічної інформації, оперативності іiі надходження та якості опрацювання залежить ефективність і своєчасність виявлення та документування кримінальних правопорушень оперативними підрозділами. 
Завдання, що стоять перед оперативними підрозділами, неможливо вирішити без забезпечення відповідної їх організації. Організаційні основи ОРД та негласної роботи - це система використання наявних оперативно-розшукових сил, засобів та методів для вирішення оперативно-розшукових завдань. Ефективність їх використання обумовлюється правильним та продуманим їх використанням [15, с. 41-42].

Розстановка сил і засобів підрозділами кримінальної поліції у функціональному плані має передбачати необхідну кількість працівників оперативних підрозділів, джерел оперативної інформації, представників громадськості, які залучаються до виконання оперативно-розшукових завдань, а також певних оперативно-розшукових засобів для забезпечення ефективної діяльності оперативних підрозділів у протидії кримінальним правопорушенням.

Відповідно до вимог ст. 8 Закону України «Про оперативно-розшукову діяльність», оперативні підрозділи наділені правом мати гласних і негласних штатних та позаштатних працівників, використовувати конфіденційне співробітництво. Стаття 275 Кримінально-процесуальний кодекс України передбачає, що під час проведення НСРД слідчий має право використовувати інформацію, отриману внаслідок конфіденційного співробітництва з іншими особами, або залучати цих осіб до проведення НСРД [16].

Поділяємо думку В.М. Плішкіна, що планування - це заздалегідь прийняте рішення про те, що робити і хто буде це робити [17, с. 312], а тому вважаємо, що при плануванні необхідно визначити й узгодити цілі та завдання на майбутнє, виробити найбільш раціональні шляхи та засоби їх досягнення з урахуванням особливостей оперативної обстановки на об'єктах обслуговування або на лініях роботи, визначити ресурсні можливості слідчого органу, а також імовірні (прогнозовані) зміни оперативної обстановки.

Завдяки плануванню (на оперативно-тактичному; управлінському та стратегічному рівнях) можуть бути вирішені такі завдання організаційного характеру: розв'язання пріоритетних (поточних і перспективних) проблем; визначення засобів досягнення поставленої мети; ефективне використання сил та засобів, робочого часу; забезпечення належного контролю.

Взаємодія оперативних підрозділів з іншими підрозділами Національної поліції України та центральними органами виконавчої влади - це комплексна діяльність, заснована на законах і підзаконних нормативних актах, не підлеглих один одному органів з організації й узгодження цілей, місця і часу спільних дій, з розподілом компетенції, функцій, повноважень, взаємних обов'язків, які мають тимчасовий характер, а саме на період реалізації оперативної інформації, найбільш ефективному поєднанні оперативно-розшукових і процесуальних дій та розслідування кримінальних проваджень.

Аналізуючи норми КПК України [18] та відомчі нормативно-правові акти Міністерства внутрішніх справ і Національної поліції України, можна виокремити такі процесуальні форми взаємодії слідчих, працівників оперативних підрозділів та інших служб поліції:

1) взаємодія при отриманні органами Національної поліції заяв і повідомлень про кримінальні правопорушення та реагування на них;
2) створення слідчо-оперативної групи для розслідування кримінальних правопорушень;

3) виконання співробітниками оперативного підрозділу письмових доручень про проведення СРД та НСРД під час досудового розслідування;

4) взаємодія при зупиненні досудового розслідування в разі, якщо підозрюваний переховується від органів слідства з метою ухилення від кримінальної відповідальності та його місцезнаходження невідоме;

5) взаємодія при направленні оперативним підрозділом матеріалів за результатами ОРД до органу досудового розслідування.

Контроль виконання запланованих заходів - це процес забезпечення досягнення належною організацією оперативної роботи поставлених цілей. Налагоджена система контролю сприяє своєчасній поінформованості керівника оперативного підрозділу про стан організації ОРД та негласної роботи підпорядкованими йому працівниками, яка дає змогу забезпечити об'єктивний аналіз діяльності за всіма ï напрямами, визначити результати їх виконання, виявлення допущених відхилень від відповідних нормативних установлень, принципів організації та регулювання діяльності, яка перевіряється.

Питання ж сутності контролю за негласною роботою та ОРД, передусім способів та меж його здійснення, і донині залишаються дискусійними й однозначно невирішеними. Зважаючи на сталу тенденцію до збільшення кількості зареєстрованих заяв і повідомлень про кримінальні правопорушення та неодноразово змінюваний законодавцем розподіл підслідності, що призвів до зростання навантаження на слідчих Національної поліції (передусім, шляхом проваджень про нерозкриті кримінальні правопорушення проти життя та здоров'я, економічні та службові злочини, які належать до категорії підвищеної складності), питання забезпечення відомчого контролю за діяльністю оперативних працівників і слідчих набувають особливого значення.

Висновки. Організацію ОРД та негласної роботи оперативних підрозділів Національної поліції України необхідно розглядати у двох аспектах - статичному і динамічному, тобто як стан керованої соціальної системи та як дії посадових осіб, що відповідають значенню дієслова “організовувати». Організація ОРД та негласної роботи як стан системи знаходить своє формальне вираження в положеннях нормативно-правових актів, що регулюють суспільні відносини у сфері ОРД. Як діяльність відповідних посадових осіб змістом організації ОРД та негласної роботи $є$ дії:

1) зі створення керованих систем (організаційних структур) у сфері ОРД та негласної роботи, упорядкування (розвиток) цих систем до рівня, що забезпечує найбільшу ефективність вирішення завдань ОРД та негласної роботи в певній оперативній обстановці;

2) упорядкування (налагодження) процесу управління (його окремих стадій) у сфері ОРД та негласної роботи й забезпечення оптимальних умов для прийняття й реалізації відповідних управлінських рішень;

3) дії, що є складовими управлінського циклу, тобто сам процес управління ОРД;

4) створення умов, необхідних для конкретних ОРЗ.

Окреслені дії становлять практичну реалізацію положень нормативно-правових актів, що регулюють суспільні відносини у сфері ОРД та негласної роботи. 


\section{Актуальні проблеми історико-правової та міжнародно-правової науки}

\section{Література}

1. Адізес І., Лафта Дж.К., Мільнер Б.З., Смирнов Є.А. Управляя изменениями. СПб. : Питер, 2008. 224 с.

2. Лафта Дж.К. Теория организации : учеб. пособие. Дж.К. Лафта. Москва: ТК Велби; Проспект, 2006. 416 с.

3. Мильнер Б.З. Теория организаций : учебник. 2-е изд., перераб. и доп. Москва: Инфра-М, 2002. 480 с.

4. Влезько Д.А. Проблемы организационных функций начальника следственного отделения (отдела) в расследовании: дис. канд. юрид. наук: 12.00.09. Краснодар, 2002. 166с.

5. Мамка Г.М. Начальник слідчого відділу як суб'єкт кримінально-процесуального доказування : автореф. дис. канд. юрид. наук : 12.00.09 «Кримінальний процес та криміналістика; судова експертиза, оперативно-розшукова діяльність». Київ, 2012. 24 с.

6. Фаринник В.І. Деякі аспекти перевірки начальником слідчого відділу кримінальних справ. Проблеми правознавства та правоохоронної діяльності. 2011. № 3 (46). C. 156-160.

7. Сергєєва Д.Б. Щодо визначення поняття «організація» у криміналістичній науці. Боротьба з організованою злочинністю і корупцією (теорія і практика). 2012. № 2. C. 232-240.

8. В'юнник Д.Ю. Проблеми організації розслідування крадіжок автотранспортних засобів. Теорія $і$ практика правознавства. 2014. Вип. 2 (6). С. 3-9.

9. Белкин Р.С. Курс криминалистики. Т. 2. Москва : Юристъ, 1997. 521 с.

10. Олішевський О.В. Рівні та суб'єкти організації розслідування злочинів. Форум права. 2011. № 2. C. 660-663. URL: http://www.nbuv.gov.ua/e-journals/ FP/2011-2/110ovorz.pd.
11. Грібов М.Л., Черняк А.М. Оперативні підрозділи правоохоронних органів України як суб'єкти протидії злочинності. Вісник кримінального судочинства. 2018. № 4. C. 24-31.

12. Оперативно-розыскная деятельность: учебник / под ред. К.К. Горяинова, В.С. Овчинского, Г.К. Синилова, А.Ю. Шумилова. 2-е изд., доп. и перераб. Москва : ИНФРА-М, 2004. 848 c.

13. Грібов М. Л. Організація діяльності оперативних підрозділів: питання юридичного унормування. Вісник кримінального судочинства. 2016. № 3. С. 26-31.

14. Великий тлумачний словник сучасної української мови / уклад. і голов. ред. В.Т. Бусел. Київ; Ірпінь : Перун, 2009. $1736 \mathrm{c}$

15. Оперативно-розшукова діяльність : навч. посіб. / Моісеєв Є.М., Джужа О.М., Никифорчук Д.Й. та ін.; за ред. О.М. Джужі. Київ: Правова єдність, 2009. 310 с.

16. Про оперативно-розшукову діяльність: Закон від 18 лют. 1992 р. № 2135-ХІІ. Верховна Рада України. URL: http://zakon0.rada.gov.ua/laws/show/2135-12.

17. Плішкін В.М. Теорія управління органами внутрішніх справ: підручник / за ред. канд. юрид. наук Ю.Ф. Кравченка. Київ : Нац. акад. внутр. справ України, 1999. 702 c

18. Кримінальний процесуальний кодекс України: Закон України від 13 квіт. 2012 р. Верховна Рада України. URL: http://zakon3.rada.gov.ua/laws/show/4651-17.

Князєв С. М., кандидат юридичних наук, здобувач Національної академії внутрішніх справ 